\title{
AN EVALUATION OF VISUAL PRIVACY LEVEL IN RESIDENTIAL UNIT'S LAYOUTS IN KHARTOUM, SUDAN
}

Received June 21st, 2021 | Accepted August 25th, 2021 | Available online December 15th, 2021

DOI http://dx. doi. org/10.18860/jia.v6i4.12201 |

Maysa Yousif

Department of Architecture

University of Malaya

Kuala Lumpur,

Malaysia

Meso.yousif@hotmail.co.uk

\section{Aniza Abdul Aziz}

Department of Architecture

University of Malaya

Kuala Lumpur,

Malaysia

anizaziz@um.edu.my

\begin{abstract}
Visual privacy is one of the vital aspects of Islamic house designs. This paper aimed to analyze the level of visual privacy in the layout of different residential apartment unit samples in Khartoum, Sudan based on Islamic values and Sudanese culture and how modern apartment unit designs respond to these needs. Models included four units from courtyard-villas and two units from apartment buildings. The architectural layout plans, spatial relation, functions, and space zoning were applied to assess the level of visual privacy of each unit. Findings showed that the courtyard-villas had a higher degree of privacy and cultural values, reflecting more of the Sudanese lifestyle than the apartment units, even though the design of the apartment units pays more attention to the nuclear family privacy. This study would assist designers in enhancing the visual privacy in apartment unit layouts by highlighting factors that diminish or enhance the visual privacy level to create appropriate designs for Sudanese Muslims and Muslims in general.
\end{abstract}

KEYWORDS:

visual privacy, Sudanese courtyard house, apartment unit layout.

\section{INTRODUCTION}

The concept of multi-storey residential buildings is more recent in Khartoum, Sudan, than in many other parts of the world, as it was only implemented in the 1970s [1]. Khartoum has three types of residential buildings: single-storey courtyard houses, three- to four-storey apartment-villas (av) developments developed by individual owners on a former courtyard house plot, and apartment buildings developed by the government or individual developers for their own use, sale, or rental. The main reason for the transformation from single-storey courtyard houses to multi-storey building developments in Khartoum was population growth (2.3 million in 1990 to 5.9 million in 2020, according to the world's population growth review [2]), followed by economic growth in the 1990 s and development of construction industry. This evolution of housing typology has indirect impacts on Sudanese culture and lifestyle, which is associated with courtyard houses. The yard in the courtyard house is an important space used to entertain family and guests. In general, apartment units have less space than courtyard houses, which is reflected in specific spaces and functional zones, such as a separate male guest lounge that affects the visual privacy, comfort level, and hospitality culture. Moreover, the absence of a yard in an apartment building creates a need for a balcony as a breathable outdoor space to enhance the health of occupants psychologically, physically, and socially [3].
Therefore, this paper describes the aspects of visual privacy and design of the traditional courtyard house and how these aspects are reflected in the design of modern apartment units. The objective is to assist Sudanese designers in developing designs that meet Sudanese cultural needs as well as reflect Islamic values of visual privacy and gender segregation, particularly in residential apartment unit design.

\section{VISUAL PRIVACY AND THEORIES}

Pecora et al. [4] described visual privacy as the ability of occupants' family members to carry out their daily activities without being noticed or detected by non-family members or by non-mahram people for Muslims. Islam only allows free social interaction between certain male and female adult family members, known as mahram. For the females, the mahram includes father, brothers, and maternal and paternal uncles [5]. For a married female, her mahram further includes her husband and father-in-law. Otherwise, her brother-in-law is considered as a temporary mahram as long as she remains married to the husband; however, as temporary mahram, she needs to cover herself in front of her brother-in-law as if they were non-mahram. Meanwhile, Shabani et al. [6] explained that "privacy could be seen as a regulator of interaction between individuals and society, between the public and private domains". 
Shabani et al. [6] also confirmed that "having specific domains for each person or a group of people is one of the primary concerns of people". So visual privacy has two parts, namely,

i. Internal visual privacy is the relation between spaces inside the housing unit and between the unit's occupants and guests.

ii. External visual privacy is defined as the relation between occupants' privacy and their neighbors or the relation between the interior of the house and the external environment and between the occupants and the external public views. In terms of opening, the design of fenestration and fence avoids visual contact between internal and external surroundings; both considerations are through the façade maintenance of the building [7].

Visual privacy is one of the fundamental values that Muslims should abide by. The concept of privacy in the Islamic cultures is derived from the Holy Qur'an along with practices and advice of the Prophet (sunnah), which are the focal sources of lifestyle guidelines [8]. In addition, all private issues are clearly defined, from visual privacy and social environment to division of spaces [9]. To maintain their privacy, the Holy Quran and Prophet Muhammed Sunnah mentioned the importance of obtaining permission when entering another person's house [10]. In Holy Quran as translated in Sahih International: $O$ you who have believed, do not enter houses other than your own houses until you ascertain welcome and greet their inhabitants. That is best for you; perhaps you will be reminded.*. And if you do not find anyone therein, do not enter them until permission has been given to you. And if it is said to you, "Go back," then go back; it is purer for you. And Allah knows of what you do. [11]

Meanwhile, for the Prophet's sunnah: Sahl bin Sa'd (May Allah be pleased with him) reported: The Messenger of Allah (PBUH) said, "Seeking permission to enter (one's house) has been prescribed in order to restrain the eyes (from looking at something we are not supposed to look at)" [12]. Also, Abu Musa AlAsh'ari (May Allah be pleased with him) reported: The Messenger of Allah (PBUH) said permission is to be sought thrice. If permission is granted, you may enter; otherwise, go back" [13].

Obtaining permission before entering other people's homes protects their privacy; once inside, proper space division, gender segregation, screening, and privacy elements improve visual privacy and comfort for house occupants. Islam also defines family privacy as the area between mahram and non-mahram, female and male, and even at the level between parents and children privacy. No one can go beyond those levels without the permission of the other. This Islamic law must be reflected visually and acoustically in a Muslim's residential building design [8]. For example, in the design of fenestrations, such as windows, doors, opening positions, and location, provisions of louvers, screen and mashrabia, in addition to the type and transparency of construction materials [14] directly or indirectly affect the visual privacy level and interaction.

Mortada [8] divided the Islam privacy principles into three components, which are the gender segregation in space usage, the control of visual privacy and acoustic privacy, and security and safety. The methods of achieving this privacy vary, depending on culture and region, as well as the place of Muslim residence [15]. Privacy also reflects the ideas of a particular society at a particular time [16]. Rahim [14] argued that privacy has been translated into the specific physical design in different cultures and locations to meet their needs for privacy in terms of spatial layout and function, local climate, context, and social behavior. Furthermore, Al-Kodmany [17] added more factors that influence the desired degree of visual privacy, which are gender, age group, education level, socio-economic group, and lifestyle.

In some Middle East countries, the use of courtyard space, mashrabia lattice screens, and thick high walls with small windows is considered the optimum way to achieve visual privacy that is suitable for the geographic location and culture. For example, according to Abu-Gaueh [18], the privacy concept in Saudi Arabia is influenced by Islamic laws and culture, whereby gender segregation is achieved by using walls as "physical partitions" to separate spaces. Furthermore, the desert climate also contributes a huge influence, as evidenced by the provision of small windows in traditional houses, which allows for less exposure to the external environment and simultaneously reduces the external heat entering the house during the day [19]. Later, these small windows are bigger and covered with latticed mashrabia to provide natural light, natural ventilation as well as visual privacy [20].

Nevertheless, AlKhateeb et al. [21] confirmed that the general meaning of privacy in Saudi Arabia as being based on Islamic guidance and their specific culture through gender segregation in spaces is to achieve high visual privacy and comfort. Therefore, this culture must be respected and reflected in the design of spaces. In another study in Iran, Shabani et al. [6] described that visual privacy in a traditional Iranian courtyard house is achieved by having the external wall built high and without any opening on the façade. The openings face the internal courtyard to increase visual and acoustic privacy. It is different from the translation of privacy in a traditional Malay house, in which the houses are built on stilts, lifted above the ground to be higher than the eye level with big windows and screens provided for natural ventilation and light, thus, the house and occupants are safe from flood and wild animals of the tropical jungle. What all Muslim houses have in common is the clear gender segregation through space layout between the male and female domain. Culture, geography, and climatic conditions affect the achievement of visual privacy from one community and location to another. 
Privacy is also stated in several theories, such as in the theory of human motivation [22], specifically in Maslow's pyramid of needs, which claims that human comfort, self-actualization, and privacy are at the top of the pyramid [23].

As a result, Figure 1 demonstrates factors that influence the variation in designs of residential buildings across Muslim countries.

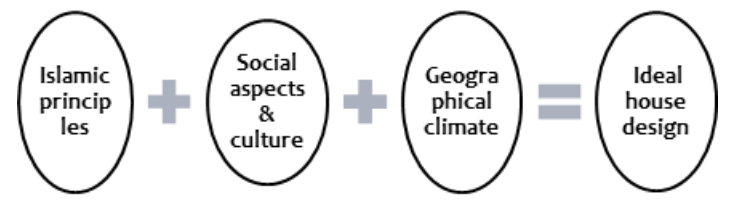

Figure 1. Factors affecting the residential building designs across Muslim countries

Hakim [24] and Rahim [14] proved that the need to provide visual privacy in unit layout and façade design for families and communities on a larger scale requires consideration of building location in relation to neighboring buildings, entrances, division of spaces into public and private domains, placement of windows, and architectural design strategies, such as the provision of louvre windows and screens or mashrabia.

Many authors have specified the public and private domains within a house layout. For example, Othman et al. [25] stated four levels of visual privacy in the design of a traditional Islamic dwelling: privacy between neighbors, between female and male, between family members in the house, and personal privacy.

Razali and Talib [5] also divided the Malay Muslim houses in Melaka, Malaysia, into four zones based on space functions and inhabitants' privacy: public, semi-public, semi-private, and private zones. The first two zones are for males, while the last two zones are for females, as illustrated in Figure 2.

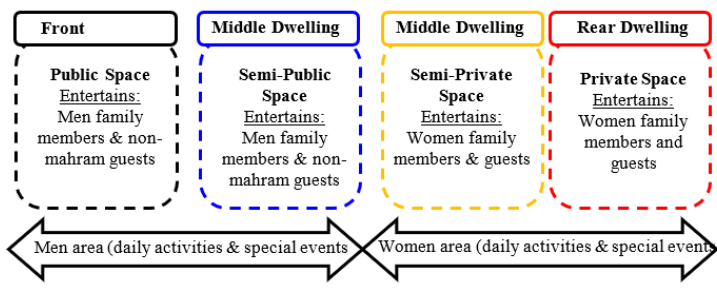

Figure 2. Privacy zones in traditional Muslim houses in Melaka, Malaysia divided according to gender and inhabitant' privacy [5]

Tomah et al. [26] conducted a visual privacy analysis on the layout of modern apartment units in Amman, Jordan, to see how the configuration of the apartment units affects the privacy of individuals. They discovered two types of layouts categorized as dual-zones and triple-zones, whereby each time the number of privacy zones increases, the level of privacy also increases. Based on space function, these zones are public, transmission, and private. The transmission or buffer zone enhances the visual privacy and comfort of family members in private spaces. The three-zone layout allows for more focus on family and female privacy from strangers and non -mahram guests. On the other hand, the buffer zone effectively reduces social interaction between occupants and guests.

\section{TRADITIONAL SUDANESE COURTYARD HOUSES}

Sudan is an African-Arab country with unique Arab and African cultural characteristics. Local building materials such as mud, strips, bricks and scattered units are more influenced by African architecture, whereby the house components are not built as a single structural unit. House privacy stems from the social structure of Arab Muslims, which relies on enclosed and private spaces [27] and [28].

The traditional Sudanese house is a singlestorey house which is designed to accommodate large families of different generations [27], especially for low-income families. One molecular family may live in a traditional courtyard house, or it may be extended to include parents, children, married children, and grandparents who live in different house sections. The parent's section, the private bedroom, is the only privacy zone; the entire family shares living spaces in the main reception area and yard. Thus, yards become the most important part of the house. At the same time, other sections of the house may have small private yards for married sons who want to maintain their privacy.

Also, the main characteristics that bind the Sudanese between extended family members, neighbors, and friends are strong social interaction, intimacy, togetherness, and cooperation. These characteristics are reflected in the number of longterm visits, especially in the past, when hotels were not widely trusted and culturally unacceptable among relatives.

\section{House's components}

Yards, kitchen, verandahs, rooms, male guest lounge, and masonry fence wall with two different entrances are all common features of traditional courtyard houses. As all the external doors and windows are accessible to the inner private yard, there is the solid fence wall around it; hence, this solid fence wall is recognized as the primary factor that contributes to each house's visual privacy by preventing outsiders from looking in [27].

The family zone consists of a kitchen, veranda, and bedrooms, whereas the male guest zone consists of a bedroom and lounge. The verandah connects all spaces, except the toilets. Toilets are built in the yard, usually at the corner of a plot and away from the house's living spaces. Each 
yard has its own designated male or female toilets.

In Arab Muslim countries, the concept of a male guest house or reception room is widely used to provide a free domain for women from nonmahram visitors [19]. The guest room could be an outward-oriented space with a separate entrance for male visitors or a separate space from the house structure. It is also a feature in the Sudanese courtyard house.

Yards

Two or more yards in a house may be divided according to their function and use, such as family and male guest yards [29]. For example, yards in Sudanese houses are located around or between building blocks. Meanwhile, in other countries like Syria, the yard is an internal courtyard in the middle of the building [30]. Regardless of its location, a yard is a social space whereby various activities are held for family and guests, such as gatherings, entertaining guests, playing, and sleeping. The yard is furnished with outdoor metal furniture, such as chairs, tables, and beds, as shown in Figure 3 . However, when the mattresses are not used during rain or dust storms, they are stored in rooms. Every day, the yard is cleaned and sprinkled with water to cool the ground and make it a more comfortable environment.

Outdoor floor mat for children to sit, pray and also break the Ramadan fast as special tradition.

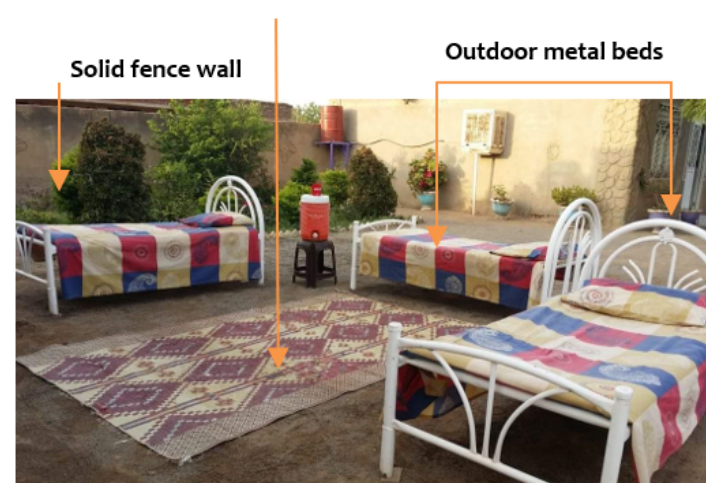

Figure 3. Yard space in a Sudanese courtyard house Source: Unknown

Entrance

There are two external entrances in traditional Arab courtyard houses, one for males and one for females. The courtyard is carefully designed to ensure privacy by using a short corridor or screening wall, which acts as a space filter so that visitors cannot see into the house, even if the door is left open to create an indirect entrance [19]. A similar technique is used in Sudanese courtyard houses as the entrances are identified by size and location. Typically, the male guest yard has a double door entrance and a secondary single door entrance facing females' backyard or service area.

\section{Bedrooms}

Besides the parent's bedroom, bedrooms serve multiple functions and cannot be classified as a private space for any single family member. It can be used by both male and female guests, with female guests in the family zone and male guests in the male zone.

\section{Veranda}

A veranda is defined as a roofed platform along the house exterior. It is located on the ground floor and often extends across both the front and sides of the structure. In addition, it can be partially enclosed by a railing or half wall [32].

A veranda is constructed from local materials, opened from the sides to provide a natural crossventilation, and protects the main building from direct solar radiation. The veranda is the most socially active space in the house because it functions as a living space, dining room, and even sleeping area during summer. In addition, the veranda may be the only living space available for a family to spend the day chatting and watching television.

\section{Privacy features and mechanism}

Traditional Sudanese house design does not prioritize individual privacy, preferring to consider privacy from a general zoning perspective, whereby non-mahram male guests should be kept out of the family circulation area. At the same time, females are allowed to enter the male zones in the presence of mahram relatives.

Figure 4 and Figure 5 represent the typical middle-income single-family home in Khartoum in the 1980s. These houses are primarily divided into two main zones: the family zone and the male guests' zone. Internally there are three different levels of privacy zone denoted in green (private), grey (semi-private), and blue colors (semi-public). To maintain the visual privacy of the female domain area, these two zones are physically separated but are connected by an internal door or free-standing walls or plants [29], such as in Figure 4.

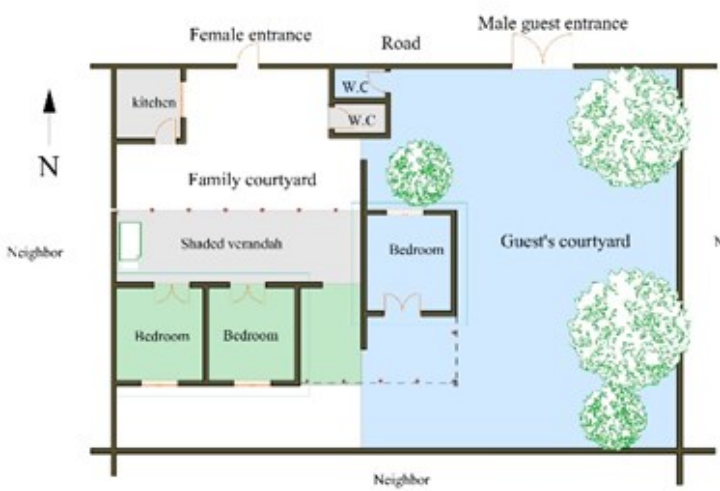

Figure 4. Traditional courtyard houses with three bedrooms. Two- sides layout [33] 


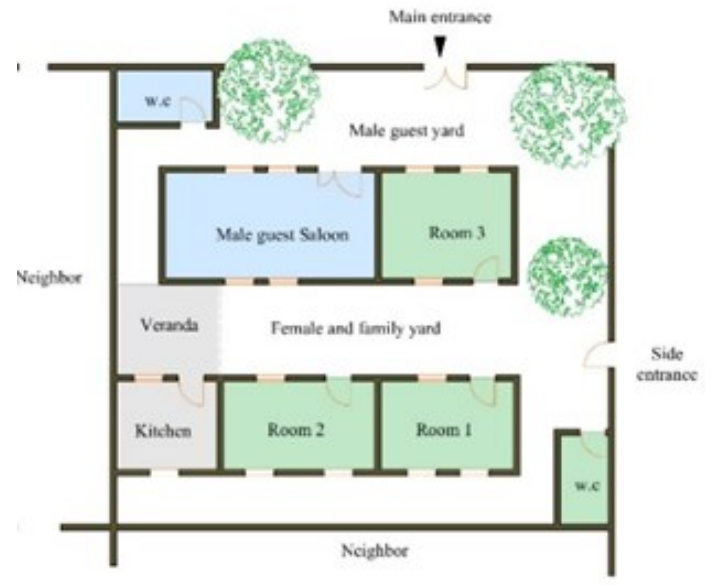

Figure 5. Traditional courtyard houses with three bedrooms. Two -layer layout [33]

Since people develop the design of the traditional house according to their needs [29], courtyard houses have several important criteria that reflect Sudanese culture, Islamic religion, and privacy level:

- $\quad$ Solid fence wall to provide privacy and security for the yards and interior spaces.

- $\quad$ Two separate entrances, one facing the front yard for male guests and the other facing the family yard for female guests or services.

- $\quad$ Two separate yards: one for male guests and social activities and one for female guests and services.

- Gender segregation between family and nonmahram visitors.

- A male guest room is available for long-term stays.

- Provision of a veranda or other communal living areas for the family and female guests.

- The kitchen is in the female zone.

- $\quad$ Except for the parent's room, other rooms have multiple functions.

All the above criteria distinguish Sudanese courtyard houses. However, to achieve all these characteristics in apartment units necessitates creativity in layout and the availability of sufficient space. Furthermore, these spaces are necessary due to hot weather, economic problems, and social requirements. Sudan is a third-world country, which is reflected in the high frequency of power outages, and the majority of its population has low income. Therefore, it will not be able to provide electricity generators. In this circumstance, the value of outdoor spaces such as veranda and yards to align with the weather and economic situation is important. Nonetheless, providing two different zone domains, one for a family as a living space and the other for male visitors, is critical for visual privacy.
If these traditional Sudanese houses in Figure 4 and Figure 5 are evaluated using prospective privacy standards, they will be classified as a low visual privacy level design; however, for the inhabitant, it has an acceptable level of privacy due to the provision of the female zone and male guest zone.

The transition from single-storey courtyard dwellings into multi-storey buildings has impacted the Sudanese people's cultures and traditions. The impact is seen in the apartment unit's size which is smaller than the courtyard house, resulting in the vanishing of certain spaces such as the yard, verandah, and guest's lounge. Also, the fence wall, which is the main element of visual privacy and security, is currently not available in the apartment unit, resulting in exposed face and windows to neighbor's eye view. Therefore, improving visual privacy in multi-storey residential buildings is essential in all Muslim communities, not just in Khartoum.

Meanwhile, in today's architectural design for dwellings, the courtyard house concept for visual privacy and gender segregation between mahram and non-mahram should not be abandoned. Residential design should not only be based on climatic response and passive design techniques to provide a constructed environment that feels connected to its surroundings [34] but rather integrate the needs of the occupants for privacy while making efficient use of spaces to meet the Islamic concept and cultural needs.

\section{CASE STUDIES AND ANALYSIS}

As case study samples, six residential units were chosen to investigate the visual privacy level in apartment units from two apartment buildings, respectively from national and private projects, and four privately owned courtyard-villas (AV), as described in Table 1 . These units have unique planning strategies with certain similarities and differences related to the layout of spaces, internal and external privacy features, and the different balcony designs resulting in different levels of visual privacy.

Table 1. Case study sample types and location within Khartoum

\begin{tabular}{|c|c|c|}
\hline $\begin{array}{l}\text { Case } \\
\text { study No }\end{array}$ & Type & Location \\
\hline Case & Al-awda complex (AP) & Suba \\
\hline study 1 & $\begin{array}{l}\text { National project by the } \\
\text { Ministry of housing funds. }\end{array}$ & \\
\hline $\begin{array}{l}\text { Case } \\
\text { study } 2\end{array}$ & $\begin{array}{l}\text { Mushaireb Qatari Diar } \\
\text { Residence. An investment } \\
\text { private project }\end{array}$ & $\begin{array}{l}\text { Khartoum } \\
\text { North }\end{array}$ \\
\hline $\begin{array}{l}\text { Case } \\
\text { study } 3\end{array}$ & $\begin{array}{l}\text { private apartment-villa } \\
\text { (AV) }\end{array}$ & Omdurman \\
\hline $\begin{array}{l}\text { Case } \\
\text { study } 4\end{array}$ & $\begin{array}{l}\text { private apartment-villa } \\
\text { (AV) }\end{array}$ & Taif \\
\hline $\begin{array}{l}\text { Case } \\
\text { study } 5\end{array}$ & $\begin{array}{l}\text { private apartment-villa } \\
\text { (AV) }\end{array}$ & Omdurman \\
\hline $\begin{array}{l}\text { Case } \\
\text { study } 6\end{array}$ & $\begin{array}{l}\text { private apartment-villa } \\
\text { (AV) }\end{array}$ & Ma'mora \\
\hline
\end{tabular}


The spaces of these units are divided into four privacy zones. The color coding system used as defined in Table 2 follows the analysis of Razali and Talib [5] and Tomah et al. [26] methods, which deals with the expected activities in the spaces to the gradient of the privacy zones.

\begin{tabular}{|c|c|c|c|c|}
\hline Zones & Public & $\begin{array}{l}\text { Semi- } \\
\text { public }\end{array}$ & $\begin{array}{c}\text { Semi- } \\
\text { private }\end{array}$ & $\begin{array}{l}\text { Private } \\
\text { zone }\end{array}$ \\
\hline \multicolumn{5}{|l|}{$\begin{array}{l}\text { Color } \\
\text { code }\end{array}$} \\
\hline $\begin{array}{l}\text { Definition } \\
\text { of zones }\end{array}$ & $\begin{array}{c}\text { Entrance } \\
\text { + Open } \\
\text { Balcony } \\
\text { without } \\
\text { screens + } \\
\text { Yard }\end{array}$ & $\begin{array}{c}\text { Guest } \\
\text { area + } \\
\text { Guest } \\
\text { toilet + } \\
\text { Balcony } \\
\text { with } \\
\text { screens. }\end{array}$ & $\begin{array}{l}\text { Kitchen + } \\
\text { Family } \\
\text { living hall } \\
\text { + Dining } \\
\text { room }\end{array}$ & $\begin{array}{c}\text { Bedroom } \\
\text { s+ Toilet } \\
+ \text { Balcony } \\
\text { with } \\
\text { screens. }\end{array}$ \\
\hline Users & \multicolumn{2}{|c|}{ Guest's zone } & \multicolumn{2}{|c|}{ Family zone } \\
\hline
\end{tabular}

The analytical method for the case studies depended on the analysis of the layout plans, the definition of entrances, categorization of spaces according to function, assessment of the privacy zone arrangements, and finally, the reporting of activities on the balcony.

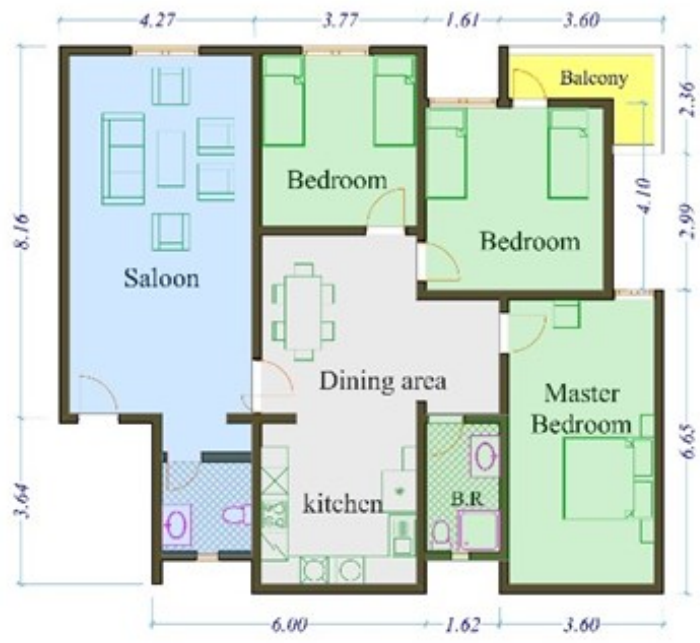

Figure 6. Case study 1; Al-awda Complex [35]

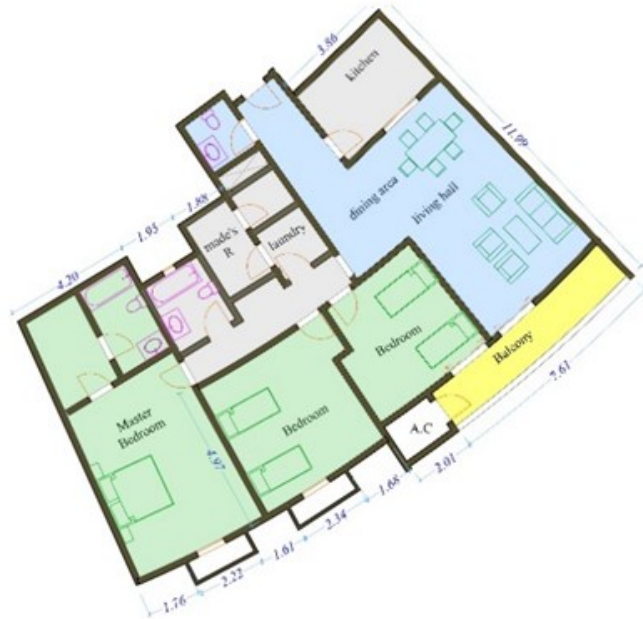

Figure 7. Case study 2; Mushaireb Qatari Diar Residence [36]

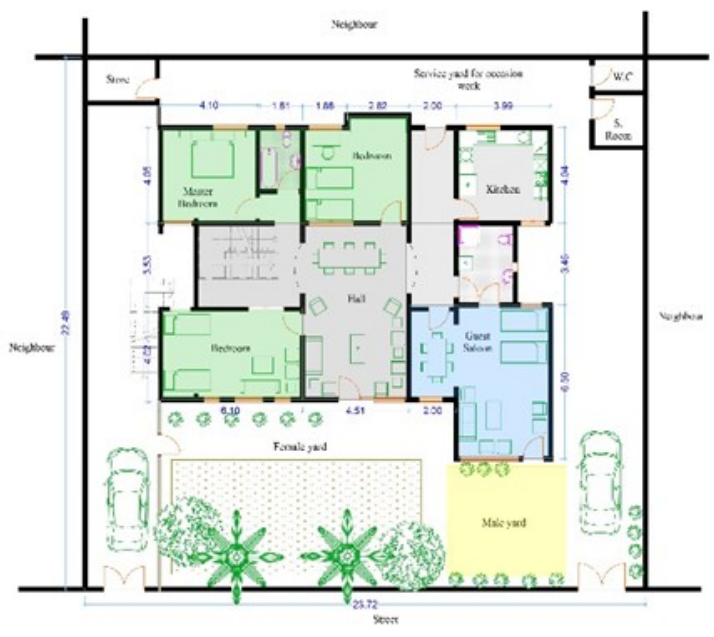

Figure 8. Case study 3; private apartment-villa

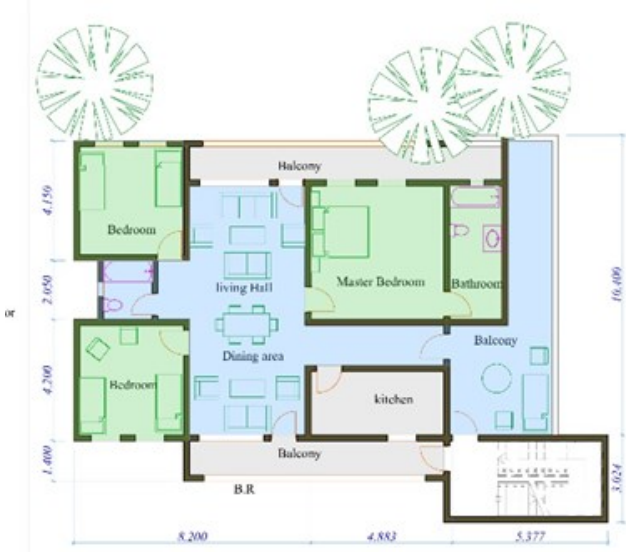

Figure 9. Case study 4; private apartment-villa 

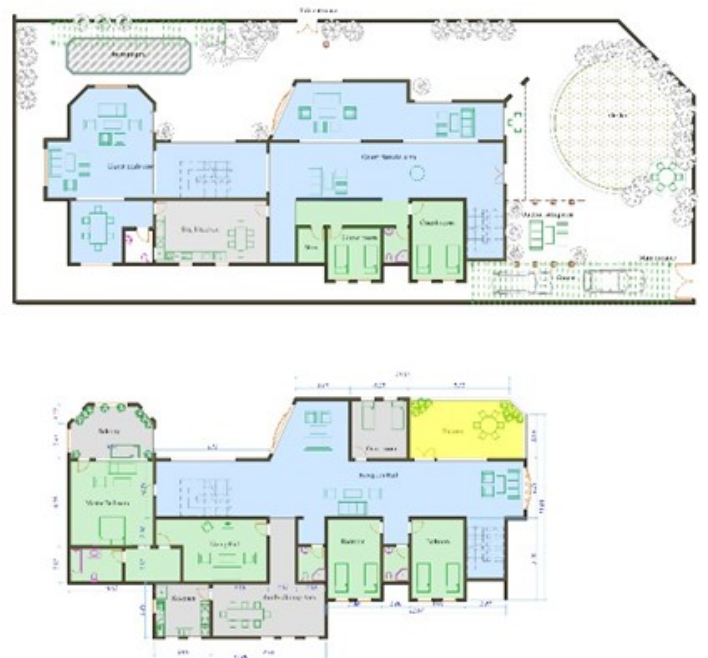

Figure 10. Case study 5; private apartment-villa.

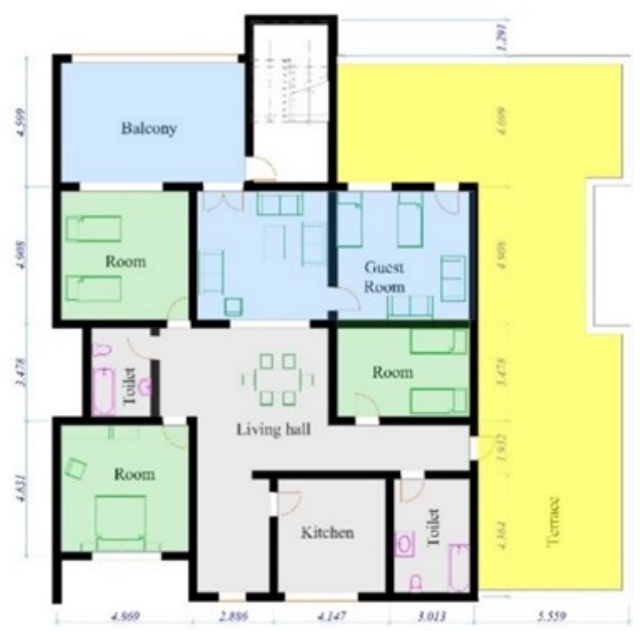

Figure 11: Case study 6; private apartment-villa with the ground and first-floor plans

\section{DISCUSSION}

Changes made to the Sudanese courtyard house into apartment-villa and apartment unit layout through the arrangement of spaces and functions may have diverse effects on the comfort and privacy of occupants. Negative effects are when one of the main spaces that enhance gender segregation and culture of the Sudanese, such as the guest room or saloon, is no longer available in the layouts.

\section{Entrance design and location}

The entrances to courtyard houses and apartment buildings are treated differently. The entrance to courtyard houses faces the yard in case study 3 (Figure 8), whereas the entrance to apartment units faces directly the living space in the case study 1 (Figure 6). Meanwhile, in case study 2 (Figure 7), a small corridor is added to prohibit direct view into the inner space.

The use of a balcony located at the entrance of the apartment unit, as proposed in Figure $12(\mathrm{~A})$, is a creative way of creating an indirect entrance, as in case study 4 (Figure 9); and case study 5, Figure 10. This treatment has two primary advantages: it creates a semi-private zone before entering the living space and a reasonable size balcony that serves as a sitting area, which would work as a reception area for short-term visitors. In addition, this suggestion requires the balcony to be well protected from solar heat and serves as a semi-private area, a safe and secure space.

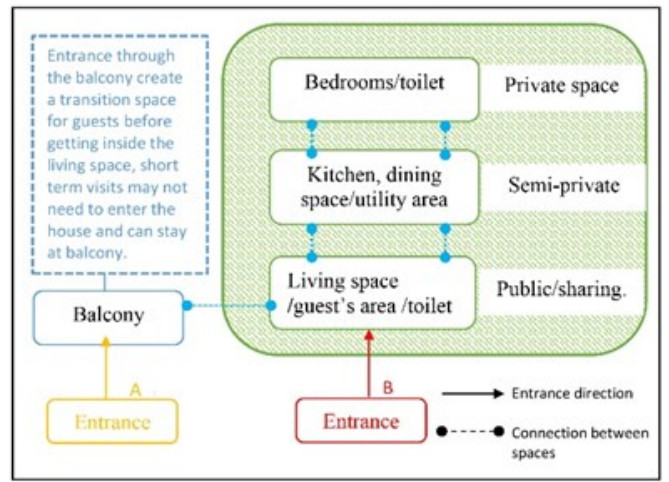

Figure 12. Proposed locations for unit entrance: $A$ - indirect entrance through the balcony and $B$ - direct entrance into the living space with attached guest toilet. (Author)

\section{Guest's receiving area}

According to Sudanese culture, a proper unit layout should consider all comfort and privacy factors to preserve the female house's privacy when male guests are present. Having a separate guest area with an attached toilet, for example, will improve family comfort and privacy. Unfortunately, as in case studies 1 and 2 (Figure 6; Figure 7), none of the apartment units has a receiving guest area separate from the family living space.

On the other hand, the apartment villa in case study 1 , case study 2 , and case study 3 ; Figure 8 , Figure 10, and Figure 11, respectively, have been specially designed space for guest, which provide more privacy for females to move around in their space without the presence of male guests.

\section{Bedrooms use and location}

The main difference between traditional houses and modern apartments can also be seen in the bedroom use and location, which become more private and limited in access to family members and room owners in modern designs as seen in all cases, except case study 4 (Figure 8); because the bedrooms here are facing the guest area which makes it less private in the presence of the guest. 


\section{Kitchen placement}

The kitchen is primarily a female domain in Sudanese culture. Therefore, it should be in the family zone rather than the public zone, such as in case study 2 (Figure 7); and case study 4 (Figure 9).

\section{Balcony design and location}

The balcony becomes a necessary space in an apartment as it is the only available outdoor space that represents the yard space. For the balcony to replace the yard in an apartment unit, considerations should be on two main things: a reasonable balcony size and shape and visual privacy feature previously available in the courtyard house. The use of privacy features such as louvers, mashrabia, screens, or plants will enhance balconies' privacy level and comfort. The materials and design of the balustrade also affect the level of privacy, security, and safety; the use of see-through materials such as glass should be avoided [37]. Also, the provision of a separate utility balcony enhances the use of the main balcony for more social routines.

Studies by Jürgenhake [38] and Safarkhani [39] indicated that the balcony space acted as a mediator layer to connect the indoor with outdoor, playing an essential role in providing privacy between the public and private rooms. Therefore, the balcony itself enhanced the privacy of the inner space.

In Case study 1 (Figure 6), the balcony in yellow color has a small size without external privacy screens. The lack of a utility room, poor balcony design, and private access forces the occupants to use the balcony area as laundry and storage spaces. Meanwhile, in case study 2 , the balcony has a long narrow shape of approximately six square meters and a width of $1.2 \mathrm{~m}$. It can only fit two chairs and a small table. It can be used for refreshment, enjoying the view of the Nile, smoking, and drying laundry. It has two accesses from the living room and bedroom, which enhances privacy, so family members can access the balcony without passing through the living room.

Case study 4 (Figure 9) has three balconies of varying functions and sizes, which enhance the unit's functionality, allowing for natural light and ventilation, and have an indirect main entrance through a large terrace balcony (marked with a red star) that works as an outdoor family and guest's area, as shown in Figure 13. This balcony area is $16 \mathrm{~m}$ square and is designated as an active social area. It is furnished with beds, tables, and chairs with a reversible degree of visual privacy; the vertical metal grill creates a semi-enclosed private space secured from the neighboring view.

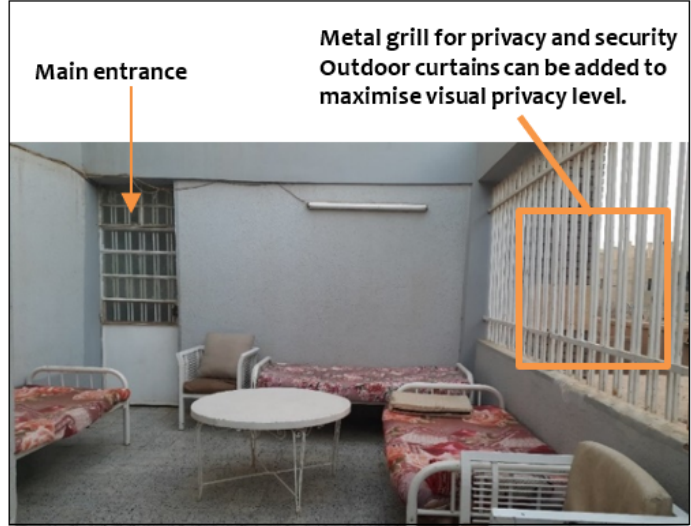

Figure 13. A view of the balcony, which is the main entrance to case study 4. Taken by the Author

Case study 5 (Figure 10) has a large balcony located at the front entrance of the unit, similar to Case study 4 . This balcony creates a space like a veranda in a traditional Sudanese house, suitable for family social activities and even guests. This balcony faces north, which makes the balcony cool in summer and sunny on winter mornings. Since the width of the balcony is 4 meters, sunlight will only penetrate the center of the balcony. Therefore, it was cool and comfortable for most of the day.

Lastly, in case study 6 (Figure 11), there are two balconies. The first balcony is a large open terrace connected to the living space shown in yellow. The balcony is furnished with a sitting area, three beds, and flowerpots. However, it can only be used in the early morning and late afternoon, as it is opened to the sky and faces a north/south direction. Meanwhile, the second balcony (Figure 14) is a private master bedroom balcony. At $12 \mathrm{~m}^{2}$, it is furnished with a traditional external Sudanese sauna, one bed, and chairs. The balustrade is a masonry wall covered from one side with a wooden mashrabia for privacy and solar protection.

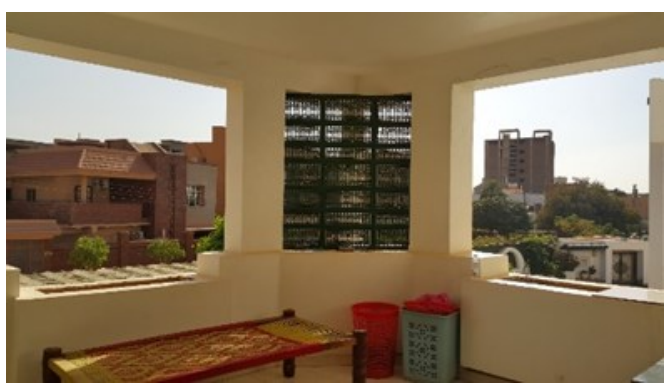

Figure 14. Case study 3: master bedroom balcony, wooden lattice mashrabia used in the western side for solar protection. (Taken by Author) 
Findings

In summary, Table 3 represents the nine design criteria driven from the principles of Islam, Sudanese culture, and the courtyard house design applied to the six case studies to evaluate the privacy levels at the scale of 1 to 3 as low, 3 to 6 as moderate, and 6 to 8 as high.

Table 3. Criteria for the level of visual privacy and comfort assessment

\begin{tabular}{|c|c|c|c|c|c|c|c|c|c|c|}
\hline 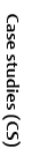 & 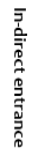 & 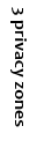 & 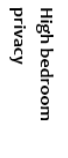 & 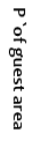 & 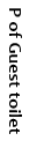 & 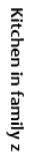 & 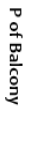 & 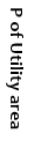 & $\begin{array}{l}0 \\
0 \\
0 \\
\hat{2} \\
\hat{0} \\
\hat{n} \\
\hat{0} \\
\vdots \\
0\end{array}$ & 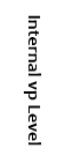 \\
\hline $\mathrm{Cs}_{1}$ & $\mathrm{x}$ & v & $\checkmark$ & v & v & $v$ & $\checkmark$ & $x$ & $\mathrm{x}$ & Moderate \\
\hline $\mathrm{CS}_{2}$ & v & $\mathrm{x}$ & $\checkmark$ & $x$ & $\checkmark$ & $\mathrm{x}$ & $\checkmark$ & $v$ & $\mathrm{x}$ & Moderate \\
\hline $\mathrm{CS}_{3}$ & $v$ & $v$ & $\mathrm{x}$ & $v$ & $v$ & $v$ & $\checkmark$ & $v$ & $\checkmark$ & High \\
\hline $\mathrm{CS}_{4}$ & $v$ & $v$ & $\mathrm{x}$ & $x$ & $\mathrm{x}$ & $\mathrm{x}$ & $v$ & v & $v$ & Moderate \\
\hline $\mathrm{Cs}_{5}$ & $v$ & $v$ & v & $v$ & $\mathrm{x}$ & $v$ & $v$ & $\mathrm{x}$ & $v$ & High \\
\hline $\mathrm{cs} 6$ & v & $v$ & $\checkmark$ & $v$ & $v$ & $v$ & $v$ & $v$ & v & High \\
\hline
\end{tabular}

As a result, the minimum number of privacy zones in all samples comprised three zones that allowed design and visual privacy [26]. However, the proper layout and positioning of these zones together are essential. For example, according to the samples studied, Case study 4 (Figure 9) has the lowest level of visual privacy and comfort due to improper space configuration, low level of privacy for bedrooms and kitchen as these spaces are located within the semi-public zone.

Case study 6 (Figure 11) has the highest level of privacy and comfort due to vertical privacy zoning, which divides the privacy zones into two different levels. The ground floor is a reception guest' level with two bedrooms for long-term visits, separate spaces for male guests and female guests, beside the main kitchen. Meanwhile, the first floor is for the family level, consisting of private bedrooms, living space, and a small kitchen. This design represents the culture of Sudanese and the value of Islam in gender segregation, high level of visual and acoustic privacy. Figure 14 explains the general concept of vertical zoning for Case study 6.

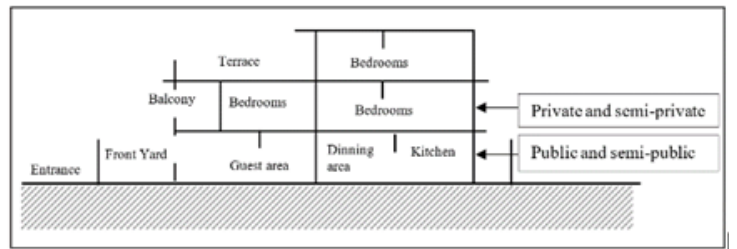

Figure 15. Case study 6 has vertical privacy zones with separate private family spaces and amenities from guests in different levels
In conclusion, there are four key findings concerning visual privacy and spatial layout as follows,

1. The number and setting of privacy zones affect the amount of privacy in residential units; a minimum of three privacy zones is recommended.

2. In apartments, an indirect entry is preferable since it improves the privacy of the interior spaces. It can be achieved via the provision of a small corridor or balcony or the use of screens.

3. The kitchen should be in the semi-private zone, considered a female space, and keep the cooking smell away from the guest area.

4. The provision of a guest area with an attached guest's toilet is a separate space from the family living space.

5. Balconies of adequate size and shape in apartment units could replace the yard space in Sudanese culture due to the need for private outdoor space.

6. Having two balconies is better than one because different balconies can serve other functions, one for entertainment and services.

\section{CONCLUSION}

This study analyzed the visual privacy in multistorey residential buildings in Khartoum and the level of comfort according to several criteria driven from the main aspect of the Sudanese traditional house designs and the principles of Islam. The modern apartment unit layout shows less consideration to gender segregation as compared to the courtyard house.

The primary design difference between private apartment villas and the national project is that the private apartment villas are designed and constructed according to the owner's preferences, beliefs, and culture, as shown in Case study 3, Case study 4, Case study 5 , and Case study 6 . In contrast, the national projects are designed in a style that would suit the most targeted population of medium to low-income group of people by providing medium-sized units, as seen in case study 1.

On the other hand, the investment projects were designed and constructed with higher standards, luxury designs, and contemporary global features to suit the contemporary culture of the targeted higherincome Sudanese and expatriates. International designs that do not relate to specific cultures prioritize family members first having their private spaces and then providing a small living room for short-term visitors. This feature appeared in the design of Case study 2 (Figure 7). This design only partially reflected the Islamic values in visual privacy. However, they do not suit the culture of hosting long-term visitors, such 
as close relatives and extended family members, while respecting the family's privacy, as seen in the layout of the traditional Sudanese courtyard.

In any style of a residential building, whether an apartment or landed house, regardless of the built-up area and cost, consideration should be given to the cultural, religion, geographical location, and needs of the local people to maintain the right level of comfort and privacy and of course the physical and mental health of occupants.

\section{REFERENCES}

[1] F. Bashier, "Modern Architecture in Khartoum 1950-1990," unpublished research paper, 2007.

[2] World Population Review. (2021). Khartoum population Available: https:// worldpopulationreview.com/world-cities/ khartoum-population

[3] R. Kisnarini, J. Krisdianto, and I. A. Indrawan, "Contribution of balcony of Rusunawa Surabaya on the use of space," E\&ES, vol. 213, no. 1, p. 012039, 2018.

[4] P. Pecora, J. Whittaker, R. Barth, A. N. Maluccio, D. DePanfilis, and R. D. Plotnick, The child welfare challenge: Policy, practice, and research. Routledge, 2017.

[5] N. H. M. Razali and A. Talib, "Aspects of Privacy in Muslim Malay Traditional Dwelling Interiors in Melaka," Procedia-Social and Behavioral Sciences, vol. 105, pp. 644-654, 2013, doi: https://doi.org/10.1016/ j.sbspro.2013.11.067

[6] M. Shabani, M. M. Tahir, H. Arjmandi, N. Abdullah, and I. Usman, "Achieving Privacy in the Iranian Contemporary Compact Apartment Through Flexible Design," Selected topics in power systems and remote sensing, pp. 285-296, 2010.

[7] F. C. Choy and S. N. Goh, "A framework for planning academic library spaces," Library management, vol. 37, no. 1/2, pp. 13-28, 2016, doi: https://doi.org/10.1108/LM-01-2016-0001.

[8] H. Mortada, Traditional Islamic principles of Built Environment. Routledge, 2003.

[9] W. N. W. Ismail et al., "The establishment of Islamic dwelling principles for the Malaysian communities," Advanced Science Letters, vol. 23, no. 7, pp. 6289-6293, 2017, doi: https:// doi.org/10.1166/asl.2017.9254.
[10] E. Alshech, "Do Not Enter Houses Other Than Your Own": the Evolution of the Notion of a Private Domestic Sphere in Early Sunnì Islamic Thought," Islamic Law and Society, vol. 11, no. 3, pp. 291-332, 2004.

[11] S. International. An-Nur, Verse (24:27) - English Translation Available: https:/ corpus.quran.com/translation.jsp? chapter $=24 \&$ verse $=27$

[12] Al-Bukhari and Muslim. Riyad as-Salihin 871 Book 5, Hadith 28. Available: https:// sunnah.com/riyadussalihin:871

[13] Al- Bukhari and Muslim. Riyad as-Salihin 870, Book 5, Hadith 27. Available: https:// sunnah.com/riyadussalihin:870

[14] Z. A. Rahim, "The Influence of Culture and Religion on Visual Privacy," Procedia - Social and Behavioral Sciences, vol. 170, pp. 537-544, 2015/01/27/ 2015, doi: https://doi.org/10.1016/ j.sbspro.2015.01.055

[15] Z. Othman, L. Buys, and R. Aird, "Observing privacy, modesty and hospitality in the home domain: Three case studies of Muslim homes in Brisbane, Australia," International Journal of Architectural Research: ArchNet-IJAR, vol. 8, no. 3, pp. 266-283, 2014

[16] S. Alitajer and G. Molavi Nojoumi, "Privacy at home: Analysis of behavioral patterns in the spatial configuration of traditional and modern houses in the city of Hamedan based on the notion of space syntax," Frontiers of Architectural Research, vol. 5, no. 3, pp. 341 352, 2016/09/01/ 2016, doi: https:// doi.org/10.1016/j.foar.2016.02.003

[17] K. Al-Kodmany, "Residential visual privacy: Traditional and modern architecture and urban design," Journal of Urban Design, vol. 4, no. 3, pp. 283-311, 1999/10/01 1999. doi: https://doi.org/10.1080/13574809908724452

[18] T. Abu-Gaueh, "Privacy as the basis of architectural planning in the Islamic culture of Saudi Arabia", Architecture and Behaviour Journal, vol. 11, no. 3, 1995, pp. 269 - 288.

[19] S. I. Dwidar, W. Metwally, and A. A. Abdelsattar, "Analytical study of heritage residential buildings in the central region of saudi arabia," Journal of Engineering Sciences Assiut University, vol. Vol. 48. No. 1, 2020, doi: DOI: 10.21608/JESAUN.2020.135077 
[20] M. S. Abbasoglu and U. U. Dagli, "Women's visual privacy analysis in traditional houses and modern apartment block neighbourhoods in Famagusta (North Cyprus)," presented at the 5th International Postgraduate Research Conference In the Built and Human Environent, University of Salford - Manchester, Jan 2019.

[21] M. S. AlKhateeb, T. Humphries-Smith, and B. Eves, "Space Design and Privacy in a Saudi House," presented at the Time, Space and the Body 3rd Global Conference, Oxford, 2014.

[22] A. H. Maslow, "Theory of Human Motivation," Psychological Review, 1943.

[23] P. Hayashi Jr, "Tattvabodha and the hierarchical necessity of Abraham Maslow," Journal of Management, Spirituality \& Religion, vol. 13, no. 2, pp. 82-93, 2016.

[24] B. S. Hakim, "Arabic-Islamic Cities," Building and planning principles, 1986.

[25] Z. Othman, R. Aird, and L. Buys, "Privacy, modesty, hospitality, and the design of Muslim homes: A literature review," Frontiers of Architectural Research, vol. 4, no. 1, pp. 1223, 2015, doi: https://doi.org/10.1016/ j.foar.2014.12.001

[26] A. N. Tomah, H. B. Ismail, and A. Abed, "The concept of privacy and its effects on residential layout and design: Amman as a case study," Habitat International, vol. 53, pp. 1-7, 2016, doi: https://doi.org/10.1016/ j.habitatint.2015.10.029

[27] K. M. Osman and M. Suliman, "Continuity and changes in the morphology of urban Sudanese homes," presented at the Transforming Housing Environments through Design, University of Pretoria, South Africa, 27-30 September, 2005.

[28] M. O. Bani, "Critical regionalism: studies on contemporary residential architecture of Khartoum - Sudan," presented at the Towards Sustainable Urban development, fourth scientific conference, Khartoum, Sudan November 9-11, 2015.

[29] A. Osman, Space, place and meaning in northern riverain Sudan, Department of Architecture, University of Pretoria, Montreal, Canada, 2004.
[30] B. Edwards, M. Sibley, P. Land, and M. Hakmi, Courtyard housing: past, present and future. Taylor \& Francis, 2006.

[31] A. Bahammam, Architectural Patterns of Privacy in Saudi Arabian Housing, Master of Architecture, McGill University, Montreal, 1987.

[32] Stefan, "What is the Difference Between a Porch, Balcony, Veranda, Patio and Deck?", homedit, 2008, Available: https:// www.homedit.com/what-is-the-differencebetween-a-porch-balcony-verandapatio-anddeck/ (accsessed 5 Aug 2018)

[33] M. Abu El Rashid, The adaptability of the courtyard house in an arid and semi-arid region (with reference to northern and central Sudan, M. Sc (Hons) arch, Department of Architecture, University of Khartoum, 1981.

[34] B. Markus, "Review of courtyard house in Nigeria: Definitions, history, evolution, typology, and functions," AFRREV STECH: An International Journal of Science and Technology, vol. 5, no. 2, pp. 103-117, 2016, DOI: 10.4314/ stech.v5i2.8

[35] Ministry of reconstruction and housing fund in Sudan, Gawharat Al'awda compound Image, 2012, Available: http://www.iskan.sd/ project.php?id=2

[36] Qatari Diar company, Mushaireb Qatari Diar Residence, 2011, Available: https:// www.qataridiar.com/English/OurProjects/ Pages/Mushaireb-.aspx

[37] R. Kennedy, L. Buys, and E. Miller, "Residents' Experiences of Privacy and Comfort in MultiStorey Apartment Dwellings in Subtropical Brisbane," Sustainability, vol. 7, no. 6, p. 7741, 2015, doi: https://doi.org/10.3390/su7067741.

[38] B. Jürgenhake, "Connecting Inside and Outside in Time-Based Dwelling," Nordic Journal of Architectural Research, vol. 19, no. 3, p. 10 pages, 2013.

[39] M. Safarkhani, Balconies consigned to oblivion in Iranian Residential building the case of Tehran, Iran, The Degree of Master of Architecture in Architecture, Department of Architecture, The Middle East Technical University, unpublished, 2016. 